\title{
Study of nano-crystalline metals prepared by selective chemical leaching
}

Dalibor Vojtěch, Alena Michalcová, Vítězslav Knotek, Ivo Marek

Department of Metals and Corrosion Engineering, Institute of Chemical Technology, Prague, Technická 5, 16628

Prague 6, Czech Republic. Dalibor.Vojtech@vscht.cz

Nano-crystalline metals with structural constituents smaller than $100 \mathrm{~nm}$ are prospective materials due to very high hardness and strength, high specific surface, chemical catalytic activity, high gas absorption capability and other characteristics. They can be produced by various methods like precipitation from liquids, vapor deposition techniques, intensive plastic deformation, rapid solidification etc. These methods enable obtaining materials of a wide range of crystallite size. The selective leaching of appropriate alloys is another method to prepare nanocrystalline metallic powders ( $\mathrm{Fe}, \mathrm{Co}, \mathrm{Cu}, \mathrm{Ni}$ etc.) with high specific surfaces. So far, these powders have been studied mainly for catalytic or magnetic purposes. But we illustrate in the present study that these powders can be successfully applied also in the development of bulk materials with a high hardness and strength (Cu) and of media with excellent hydrogen storage capacity $(\mathrm{Ni})$.

Key words: nano-crystalline metal, nickel, copper, hardness, structure

\section{Acknowledgements}

Research on nano-crystalline metals is financially supported by the Czech Science Foundation (project no. P108/12/G043).

\section{References}

[1] MEYERS, M.A., CHAWLA, K.K. (2009). Mechanical behavior of materials, CAMBRIDGE UNIVERSITY PRESS.

[2] YOUSSEF, K.M., SCATTERGOOD, R.O., MURTY, K.L., KOCH, C.C. (2006). Nanocrystalline Al-Mg alloy with ultrahigh strength and good ductility: A review. Scripta Materialia, 54, 2, pp. 251-256.

[3] KIM, H.G., MYUNG, W.N., SUMYIAMA, K., SUZUKI, K. (2005). Formation and chemical leaching of nonequilibrium $\mathrm{Al}_{0.6}\left(\mathrm{Co}_{75} \mathrm{Cu}_{25}\right)_{0.4}$ alloy powders by rod milling: A review. Journal of Alloys and Compounds, 398 , 1-2, pp. 74-79.

[4] KIM, H.G., MYUNG, W.N., SUMYIAMA, K., SUZUKI, K. (2003). Formation and chemical leaching effects of nonequilibrium $\mathrm{Al}_{0.6}\left(\mathrm{Fe}_{25} \mathrm{Cu}_{75}\right)$ alloy powder produced by rod milling: A review. Journal of Alloys and Compounds, 360, 1-2, pp. 168-172.

[5] HU, H., QIAO, M., WANG, S., FAN, K., LI, H., ZONG, B., ZHANG, X. (2004). Structural and catalytic properties of skeletal Ni catalyst prepared from the rapidly quenched Ni50Al50 alloy: A review. Journal of Catalysis, 221, 2, pp. 612-618.

[6] GOLUBKOVA, G.V., LOMOVSKI, O.I., KWON, Y.S., VLASOV, A.A., CHUVILIN, A.L. (2003). Formation of nanocrystalline structures in a $\mathrm{Co}-\mathrm{Al}$ system by mechanical alloying and leaching: A review. Journal of Alloys and Compounds, 351, 1-2, pp. 101-105.

[7] LU, H.B., LI, Y., WANG, F.H. (2007). Synthesis of porous copper from nanocrystalline two-phase $\mathrm{Cu}-\mathrm{Zr}$ film by dealloying: A review. Scripta Materialia, 56, 2, pp. 165-168.

[8] ROSS, D.K. (2006). Hydrogen storage: The major technological barrier to the development of hydrogen fuel cell cars: A review. Vacuum, 80, 10, pp. 1084-1089.

[9] CHAMPION, Y., GUÉRIN-MAILLY, S., BONNENTIEN, J.-L., LANGLOIS, P. (2001). Fabrication of bulk nanostructured materials from metallic nanopowders: Structure and mechanical behaviour: A review. Scripta Materialia, 44, 8-9, pp. 1609-1613.

[10] CARLTON, C.E., FERREIRA, P.J. (2007). What is behind the inverse Hall-Petch effect in nanocrystalline materials?: A review. Acta Materialia, 55, 11, 3749-3756. 